\title{
Molecular Mechanisms Underlying the In Vitro Anti-Inflammatory Effects of a Flavonoid-Rich Ethanol Extract from Chinese Propolis (Poplar Type)
}

\author{
Kai Wang, ${ }^{1}$ Shun Ping, ${ }^{1}$ Shuai Huang, ${ }^{1}$ Lin $\mathrm{Hu},{ }^{2}$ \\ Hongzhuan Xuan, ${ }^{1,3}$ Cuiping Zhang, and Fuliang $\mathrm{Hu}^{1}$ \\ ${ }^{1}$ College of Animal Sciences, Zhejiang University, Hangzhou 310058, China \\ ${ }^{2}$ Life Sciences Institute, Zhejiang University, Hangzhou 310058, China \\ ${ }^{3}$ School of Life Science, Liaocheng University, Liaocheng 252059, China \\ Correspondence should be addressed to Fuliang Hu; fulianghu@yahoo.com
}

Received 19 November 2012; Revised 18 December 2012; Accepted 18 December 2012

Academic Editor: José Maurício Sforcin

Copyright ( $\odot 2013$ Kai Wang et al. This is an open access article distributed under the Creative Commons Attribution License, which permits unrestricted use, distribution, and reproduction in any medium, provided the original work is properly cited.

China produces the greatest amount of propolis but there is still lack of basic studies on its pharmacological mechanisms. Our previous study found that ethanol extract from Chinese propolis (EECP) exerted excellent anti-inflammatory effects in vivo but mechanisms of action were elusive. To further clarify the possible mechanisms underlying the anti-inflammatory effects of Chinese propolis (poplar type), we utilized EECP to analyze its chemical composition and evaluated its potential anti-inflammatory effects in vitro. High-performance liquid chromatography (HPLC) profile indicated that EECP contained abundant flavonoids, including rutin, myricetin, quercetin, kaempferol, apigenin, pinocembrin, chrysin, and galangin. Next we found that EECP could significantly inhibit the production of NO, IL-1 $\beta$, and IL-6 in lipopolysaccharide- (LPS-) stimulated RAW 264.7 cells and suppress mRNA expression of iNOS, IL- $1 \beta$, and IL- 6 in a time- and dose-dependent manner. Furthermore, we found that EECP could suppress the phosphorylation of $\mathrm{I} \kappa \mathrm{B} \alpha$ and $\mathrm{AP}-1$ but did not affect $\mathrm{I} \kappa \mathrm{B} \alpha$ 's degradation. In addition, using a reporter assay, we found that EECP could block the activation of NF- $\kappa$ B in TNF- $\alpha$-stimulated HEK 293T cells. Our findings give new insights for understanding the mechanisms involved in the anti-inflammatory effects by Chinese propolis and provide additional references for using propolis in alternative and complementary therapies.

\section{Introduction}

Inflammation is an integral physiological host response to tissue injury and infection, which is vital for our body when facing invading microbes or the diseases. Several relatively abundant proinflammatory mediators and cytokines are generally characterized and have been validated their important roles in inflammatory responses, such as nitric oxide (NO), interleukin (IL-) $\beta$, and IL-6 [1]. The overproduction of these proinflammatory mediators are typically linked to proinflammatory stimuli which will cause acute or chronic inflammatory responses and being the pathogenesis of many diseases. Increasing evidence indicates that the transcription factor nuclear factor kappa $\mathrm{B}(\mathrm{NF}-\kappa \mathrm{B})$ as well as the activator protein (AP-)1 plays important roles in the immune/inflammatory responses by regulating the transcriptional activation of many inflammatory-related genes. In normal conditions, the inhibitor of $\kappa \mathrm{B}$ binding protein $(\mathrm{I} \kappa \mathrm{B})$, such as $\mathrm{I} \kappa \mathrm{B} \alpha$, interacts with p50/p65 heterodimer in the cytoplasm and masks nuclear localization sequence, so the NF- $\kappa \mathrm{B}$ dimers failed to bind to $\kappa \mathrm{B}$ sites. In inflammatory conditions, $\mathrm{I} \kappa \mathrm{B} \alpha$ will be phosphorylated then degraded by $26 \mathrm{~s}$ proteosome. This leads to the free NF- $\kappa \mathrm{B}$ to translocate into the nucleus, binding specifically to the $\kappa \mathrm{B}$ sites in the genome. AP- 1 is a family of DNA binding transcription factors composed of dimers with two proteins. The best-characterized AP-1 is composed by two proteins, namely Jun and Fos [2]. Various genes encoding for proinflammatory mediators, cytokines, chemokines, and some inducible enzymes contain $\kappa \mathrm{B}$ sites and AP-1 binding sites. The transcription of these genes is 
regulated, in a sense, by the NF- $\kappa$ B and AP- 1 activity $[3,4]$. Therefore, suppressing or inhibiting the improper activation of these inflammation-linked transcription factors may have therapeutic potential.

Propolis is a resinous substance collected by honeybees, Apis mellifera, from various plant sources [5]. Bees use propolis as a building and insulating material to protect their hives. Propolis has been used in folk medicines and complementary therapies since 3,000 BC in Egypt and has become one of the most popular functional foods all around the world. Propolis show a broad spectrum of bioactivities, such as antioxidant [6], antimicrobial [7], antitumor [8], antiviral [9], anti-ulcer [10], immunomodulatory [11], cardioprotective [12], and anti-inflammatory effects [13].

Moreover, China produces the greatest amount of propolis and has become one of the largest raw propolis exporters in the world. Comparing with propolis collected from other areas, Chinese propolis also exerted lots of beneficial properties. By contrast, very limited studies focus on its pharmacological activities and functional mechanisms [14]. Our previous study found that Chinese propolis exhibited significant anti-inflammatory effects using different animal models [15]. We also demonstrated that these effects may probably attribute to the suppression of phosphatidylcholinespecific phospholipase C (PC-PLC) and to the depression of p53 and ROS levels [16]. However, detailed molecular mechanisms of the anti-inflammatory effects by Chinese propolis have not been satisfactorily elucidated.

In the present study, as a continuing part of our research to clarify the possible mechanisms underlying the antiinflammatory effects of Chinese propolis (poplar type), we studied the total flavonoids content and analyzed the chemical composition of an ethanol extract from Chinese propolis (EECP). Furthermore, we examined effects of EECP on the in vitro inflammatory responses and inflammation-related transcription factors in lipopolysaccharide (LPS)-stimulated RAW 264.7 cells. We also evaluated effects of EECP on the activation of NF- $\kappa \mathrm{B}$ in tumor necrosis factor (TNF) $-\alpha$ stimulated HEK 293T cells. To our knowledge, this is the first time using Chinese propolis to evaluate the in-vitro antiinflammatory effects in activated macrophages and effects of Chinese propolis on NF- $\kappa \mathrm{B}$ activation is highlighted.

\section{Materials and Methods}

2.1. Chemicals and Reagents. LPS (Escherichia coli 0127:B8) and alkaline phosphatase-conjugated secondary antibody (anti-rabbit IgG) and the standards used in HPLC analysis were purchased from Sigma-Aldrich (St Louis, USA). Primary rabbit monoclonal antibodies against phosphoc-Jun (pS63), phospho- $\mathrm{I} \kappa \mathrm{B} \alpha(\mathrm{pS} 36)$, and $\beta$-tubulin were purchased from Epitomics (Burlingame, CA, USA). The polyclonal anti-rabbit $\mathrm{I} \kappa \mathrm{B} \alpha$ antibody was a generous gift from Professor Zongping Xia (Life Sciences Institute, Zhejiang University, China). Other chemicals were purchased from Sangon Biotechnology Co. Ltd. (Shanghai, China).

2.2. Preparation of Ethanol Extract from Raw Chinese Propolis. Raw Chinese propolis sample was collected from A. mellifera colonies in Shandong province which is located in North China at the summer of 2010 and stored at $-20^{\circ} \mathrm{C}$ until used. Main plant origin of the propolis sample collected was poplar (Populus sp.). For the subsequent experiments, one hundred grams of propolis sample was weighed and broken into powders with a grinder. Then the propolis sample was extracted by $95 \%(\mathrm{v} / \mathrm{v})$ ethanol $(1 \mathrm{~L})$, sonicated at $40^{\circ} \mathrm{C}$ for $3 \mathrm{~h}$. After the sonication, the supernatant was filtered with Whatman No. 4 filter papers to remove the residues. The residues were collected then extracted and sonicated with $95 \%$ ethanol for another $3 \mathrm{~h}$. The raw propolis was extracted for three times. Thereafter, all of the supernatants were collected together and evaporated in a rotary evaporator under a reduced pressure at $50^{\circ} \mathrm{C}$. Finally, the extract was dried in the oven until reaching a constant weight and stored at $-20^{\circ} \mathrm{C}$ until further used. During the cell experiments, the final extract was weighed and redissolved in $100 \%$ ethanol. Ethanol extract of Chinese propolis (EECP) solution was filtered with $0.22 \mu \mathrm{m}$ syringe filters (Pall, USA) to make $20 \mathrm{mg} / \mathrm{mL}$ stock and stored at $-20^{\circ} \mathrm{C}$ in the dark. Final concentration of ethanol in the cell culture medium did not exceed than $0.1 \%(\mathrm{v} / \mathrm{v})$.

\subsection{Total Flavonoids Measurement and HPLC Analysis.} Total flavonoids content of propolis extract was measured using the method of Chinese Standard (GB/T 20574-2006). The absorbance reading was determined by an Ultraviolet Specterphotometry (UV-2550, SHIMADZU Co., Japan) at $415 \mathrm{~nm}$. The chromatographic analyses were carried out using the method of Chinese Standard (GB/T 19427-2003) and operated on an Agilent HPLC system equipped with a vacuum degasser G1322A, a quaternary pump G1311A, an autosampler G1329A, a programmable variable wavelength detector (VWD) G1314B, and a thermostated column compartment G1316A. Separation of flavonoids was performed on Sepax GP-C18 column $(4.6 \mathrm{~mm} \times 150 \mathrm{~mm}, 3 \mu \mathrm{m})$ at $28^{\circ} \mathrm{C}$ with a detection wavelength at $270 \mathrm{~nm}$. The mobile phases were consisted of methanol and water at a ratio of 58/42 (v/v) and the $\mathrm{pH}$ value was adjusted to 3 with phosphoric acid at a flow rate of $0.7 \mathrm{~mL} / \mathrm{min}$. All of the sample solutions were filtered through $0.22^{\circ} \mu \mathrm{m}$ membrane filters with an injection volume of $10 \mu \mathrm{L}$.

2.4. Cell Culture and Cell Viability Evaluation by MTT Assay. Murine macrophages-like cell line RAW 264.7 and human embryonic kidney (HEK) 293T cells originated from the American Type Culture Collection (ATCC) and cultured in DMEM (high glucose) supplemented with $100 \mathrm{U} / \mathrm{mL}$ of penicillin, $100 \mu \mathrm{g} / \mathrm{mL}$ streptomycin and $10 \%$ heat-inactivated fetal bovine serum (Gibco, USA) at $37^{\circ} \mathrm{C}$ and $5 \% \mathrm{CO}_{2}$ in a humidified incubator. Effect of EECP on the viability of RAW 264.7 cells was determined by 3-(4,5-dimethylthiazol-2-yl)2,5-diphenyltetrazolium bromide (MTT) assay as previously described [17] using the MTT Cell Proliferation and Cytotoxicity Assay Kit (Beyotime, Beijing, China) according to manufacturer's instructions. The optical density values were measured at $570 \mathrm{~nm}$ using an ELISA reader (Bio-Rad 680, USA). 
2.5. NO Measurement by Greiss' Reaction and Cytokine Determination by ELISA. Murine RAW 264.7 cells $\left(1.2 \times 10^{5}\right)$ were seeded into 24 -well plates and cultured for $24 \mathrm{~h}$, thereafter the cells were pretreated with specified concentrations of EECP for $1 \mathrm{~h}$ then the cells were stimulated with $1 \mu \mathrm{g} / \mathrm{mL}$ LPS. After incubating at designated length of time, the cell medium was collected and centrifuged, then dispensed and stored at $-80^{\circ} \mathrm{C}$ until tested. The amount of the inflammatoryrelated cytokines, IL- $1 \beta$ and IL- 6 in the cell culture supernatants was measured using enzyme-linked immunosorbent assay (ELISA) kits, according to manufacturer's instructions (Sunny ELISA Kits, Mutisciences, Hangzhou, China). The generation of nitric oxide was assayed using a $\mathrm{NO}$ measurement kit by a colorimetric Griess' method (Beyotime, Beijing, China). The optical density was measured at $450 \mathrm{~nm}$ for IL$1 \beta$ and IL- 6 and at $550 \mathrm{~nm}$ for NO using the ELISA reader (Bio-Rad 680, USA).

2.6. Total RNA Isolation and Reverse Transcription. Total RNA was isolated from RAW 264.7 cells using an E.Z.N.A total RNA Kit (Omega Bio-tech Inc., USA) following the protocol provided by the manufacturer. The purity and concentration of all RNA samples were measured using a Nano Drop spectrophotometer (ND-2000, NanoDrop Technologies, USA). Total RNA samples were suspended in DEPC-treated water and stored at $-80^{\circ} \mathrm{C}$ until further used. For cDNA synthesis, $1 \mu \mathrm{g}$ of total RNA were used in a $25 \mu \mathrm{L}$ reaction volume using a First-Strand cDNA synthesis kit (GeneCopoeia, USA). The reaction products of reverse transcription were kept frozen at $-20^{\circ} \mathrm{C}$ until used.

2.7. Quantitative Real-Time Polymerase Chain Reaction Anal$y$ sis. All of the oligonucleotide primers used were designed using the Perlprimer software and synthesized commercially (Sangon Biotechnology, Shanghai, China). The sequences of the primers were as follows: murine GAPDH sense, $5^{\prime}$ GAGAAACCTGCCAAGTATGATGAC-3', GAPDH antisense, $5^{\prime}$-TAGCCGTATTCATTGTCATACCAG-3'; IL- $1 \beta$ sense, $5^{\prime}$-CCAACAAGTGATATTCTCCATGAG-3', IL-1 $\beta$ anti-sense, 5 -ACTCTGCAGACTCAAACTCCA-3'; IL-6 sense, 5 '-CTCTGCAAGAGACTTCCATCC-3', IL-6 antisense, 5'-GAATTGCCATTGCACAACTC-3'. iNOS sense, 5 '-TTTCCAGAAGCAGAATGTGACC-3', iNOS anti-sense, 5 -AACACCACTTTCACCAAGACTC- 3 . Suitable sizes of synthesized cDNA were $239 \mathrm{bp}$ for IL-1 $\beta, 210 \mathrm{bp}$ for IL-6, $294 \mathrm{bp}$ for iNOS, and $212 \mathrm{bp}$ for GAPDH. Quantitative realtime PCR was performed with the Mastercycler ep realplex (Eppendorf, Hamburg, Germany) using a SYBR premix EX Taq (TaKaRa, Dalian, China) following manufacturer's protocols. The reactions were carried out in duplicate in a $25 \mu \mathrm{L}$ reaction volume in a 96-well plate format and the reaction mixtures with no cDNA served as negative control. The 2-steps PCR reaction condition was as follows: initial denaturation at $95^{\circ} \mathrm{C}$ for $30 \mathrm{~s}$, followed by 40 cycles of denaturation at $95^{\circ} \mathrm{C}$ for $5 \mathrm{~s}$, annealing and extension at $60^{\circ} \mathrm{C}$ for $30 \mathrm{~s}$, followed by the confirmation with the melting curve analysis at $95^{\circ} \mathrm{C}$ for $15 \mathrm{~s}, 50^{\circ} \mathrm{C}$ and $95^{\circ} \mathrm{C}$ for $15 \mathrm{~s}$. The real-time
PCR products were also confirmed by DNA sequencing and electrophoresed with 1.5\% agarose gel after staining by GoldView (SBS Genetech, Beijing, China), visualized under UV light. GAPDH was used as a housekeeping gene to normalize the expression of the target genes (IL-1 $\beta$, IL-6, and iNOS) using a ${ }^{\Delta \Delta} \mathrm{Ct}$ method [18].

2.8. Cellular Protein Extraction and Western Blotting Analysis. RAW 264.7 cells were pretreated with assigned concentrations of EECP for $1 \mathrm{~h}$. Then the cells were stimulated with $1 \mu \mathrm{g} / \mathrm{mL}$ LPS at pre-designed time points. At the harvest time, the cells were put on the ice immediately and washed twice with cold PBS. Then the cells were lysed on ice for $10 \mathrm{~min}$ using a cell lysis buffer containing $50 \mathrm{mM}$ Tris- $\mathrm{Cl}$ ( $\mathrm{pH}$ 7.5), $150 \mathrm{mM} \mathrm{NaCl}, 0.5 \%$ NP-40, $10 \%$ glycerol, $2 \mathrm{mM}$ DTT, $1 \mathrm{mM}$ leupeptin, and $1 \mathrm{mM}$ PMSF. All the lysate were collected by scraping with the cell scrapers (Corning, USA) and centrifugated at $4^{\circ} \mathrm{C}$ at a speed of $12,000 \mathrm{~g}$ for $10 \mathrm{~min}$ to remove cell debris. After that, equal amounts of cellular protein $(30 \mu \mathrm{g})$ were mixed with a quarter-volume of the Laemmli's sample buffer and boiled at $95^{\circ} \mathrm{C}$ for $5 \mathrm{~min}$. Then the cellular proteins were separated by $12-15 \%$ sodium dodecyl sulfatepolyacrylamide gel electrophoresis (SDS-PAGE). Afterwards, the gels were transferred to polyvinylidene fluoride (PVDF) membranes and 5\% skim milk dissolved in Tris-buffered saline Tween 20 (TBST, $20 \mathrm{mM}$ Tris- $\mathrm{Cl}, \mathrm{pH} 7.4,150 \mathrm{mM}$ $\mathrm{NaCl}$, and $0.02 \%$ Tween 20 ) was used to block the nonspecific binding sites on the PVDF membrane (Millipore, USA) for $30 \mathrm{~min}$ at room temperature. Then the blots were incubated with primary antibodies for $1 \mathrm{~h}$ at room temperature or $4^{\circ} \mathrm{C}$ overnight. Thereafter, the membranes were washed for three times with TBST and incubated with a $1: 10,000$ dilution of alkaline phosphatase-conjugated secondary antibody for $1 \mathrm{~h}$ at room temperature. After another three times washing with TBST, the immunoreactive protein bands on the membrane were developed for $3 \mathrm{~min}$ in $10 \mathrm{~mL}$ alkaline phosphatase for western color development buffer $(100 \mathrm{mM}$ Tris-Cl, $\mathrm{pH}$ 9.5, $50 \mathrm{mM} \mathrm{NaCl}$ and $5 \mathrm{mM} \mathrm{MgCl}_{2}$ ) mixed with $100 \mu \mathrm{L}$ NBT/BCIP solution $(18.75 \mathrm{mg} / \mathrm{mL}$ Nitro blue tetrazolium chloride, NBT and $9.4 \mathrm{mg} / \mathrm{mL}$ 5-bromo-4-chloro-3-indolyl phosphate toluidine salt, BCIP in $67 \% \mathrm{DMSO}, \mathrm{v} / \mathrm{v})$. The Western blotting results were evaluated using Quantity one software if necessary.

2.9. Transient Transfection and NF- $\kappa B$ Reporter Assay. In order to examine the effect of EECP on NF- $\kappa \mathrm{B}$ activation, HEK 293 T cells were plated in 12 -well plates at $1.5 \times 10^{5}$ cells per well and incubated overnight. Cells were transfected the next day with $30 \mathrm{ng}$ of firefly luciferase reporter plasmid (pGL4.2-3 $\times$ NF- $\kappa$ B-Luc) and $5 \mathrm{ng}$ of sea pansy luciferase reporter plasmid (pRL-TK). Total expression plasmids are $500 \mathrm{ng}$ and the pcDNA3.1 vector was added as needed to make up the total amount of expression plasmid DNA. $24 \mathrm{~h}$ after transfection, cells were pretreated with various concentrations of EECP solutions (from 0 to $20 \mu \mathrm{g} / \mathrm{mL}$ ) for $1 \mathrm{~h}$, then stimulated with $10 \mathrm{ng} / \mathrm{mL}$ of TNF- $\alpha$ for $12 \mathrm{~h}$. Cell viability was confirmed by trypan blue exclusion and microscopy examination. Then the cells were washed with cold PBS twice 


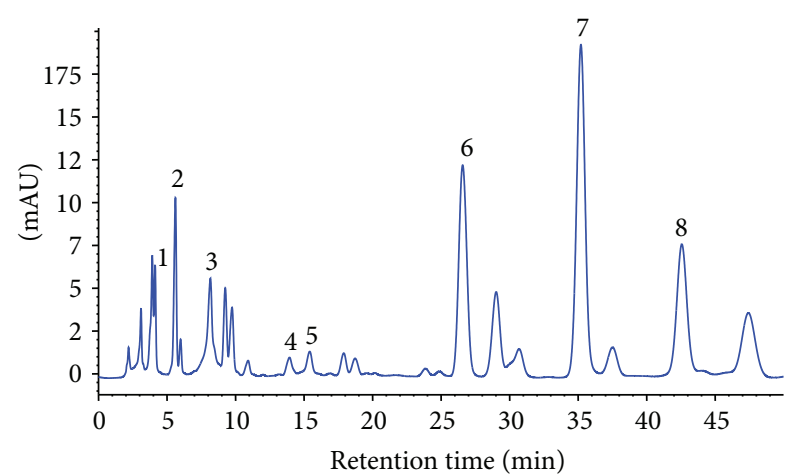

(a)

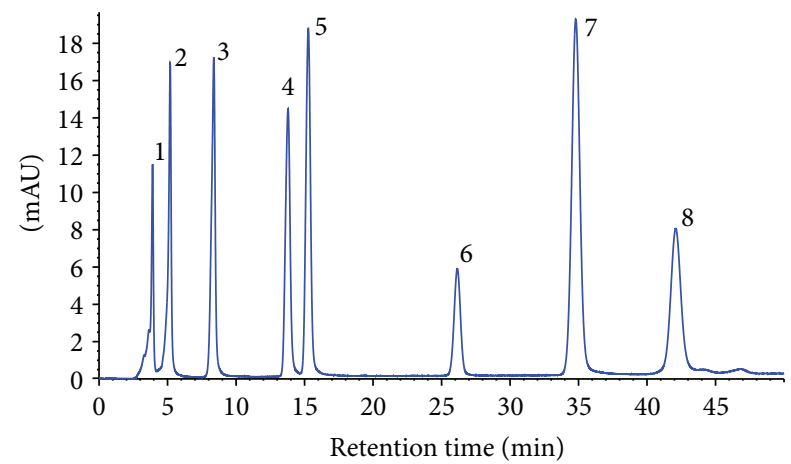

(b)

Figure 1: HPLC chromatogram of (a) EECP and (b) flavonoids standards. Peaks: (1) rutin; (2) myricetin; (3) quercetin; (4) kaempferol; (5) apigenin; (6) pinocembrin; (7) chrysin; and (8) galangin.

TABLE 1: Concentrations of flavonoids presented in EECP.

\begin{tabular}{lcc}
\hline Compounds & Retention Time $(\mathrm{min})$ & $\mathrm{mg} / \mathrm{g}$ of extract \\
\hline Rutin & 4.13 & $18.8 \pm 0.1$ \\
Myricetin & 5.61 & $15.4 \pm 0.2$ \\
Quercetin & 8.16 & $19.7 \pm 0.3$ \\
Kaempferol & 13.94 & $3.7 \pm 0.1$ \\
Apigenin & 15.41 & $3.5 \pm 0.1$ \\
Pinocembrin & 26.57 & $84.6 \pm 0.2$ \\
Chrysin & 35.20 & $33.5 \pm 0.1$ \\
Galangin & 42.57 & $29.1 \pm 0.2$ \\
\hline
\end{tabular}

Reported values are the means \pm SD $(n=3)$. EECP, ethanol extracts of Chinese propolis.

and harvested in the cell lysis buffer (0.5\% CHAPS, $25 \mathrm{mM}$ glycylglycine, $15 \mathrm{mM} \mathrm{MgSO}_{4}$ and $4 \mathrm{mM}$ EGTA, $1 \mathrm{mM}$ DTT and PMSF). After that, the cell lysate were kept on the shaker at room temperature for $20 \mathrm{~min}$, then transferred to the ice. Afterwards, move the lysate to Eppendorf tubes and spinned for 10 minutes at $12,000 \mathrm{~g}$. Firefly and sea pansy luciferase activities were quantified using a DLReady luminometer (Berthold Technologies, Germany), with firefly luciferase activity normalized for transfection efficiency based on sea pansy luciferase activity.

2.10. Statistical Analysis. All data are representative of at least three independent experiments. Data are presented as mean $\pm \mathrm{SD}$ and student's $t$-test was used to demine the statistical significance between two groups and $P$ value of $<0.05$ was considered to be statistically significant.

\section{Results}

3.1. Total Flavonoids Content of EECP and Phytochemical Analysis by HPLC. The chromatographic profile of EECP and the flavonoid standards were recorded at $270 \mathrm{~nm}$ in Figure 1 and their amounts are shown in Table 1. Total flavonoids content of EECP was $227.24 \pm 1.01 \mathrm{mg}$ rutin equivalent per gram using a colorimetric method. We also analyzed eight most representative flavonoids of poplar tree type propolis, namely rutin, myricetin, quercetin, kaempferol, apigenin, pinocembrin, chrysin, and galangin. The HPLC file showed that all of the eight flavonoids are presented in EECP, in accordance with previous study [19].

3.2. Assessment of Cell Toxicity of EECP in RAW 264.7 Cells. Cytotoxicity of EECP on RAW 264.7 cells is shown in Figure 2(d). After incubating for $24 \mathrm{~h}, \mathrm{EECP}$ at concentrations up to $20 \mu \mathrm{g} / \mathrm{mL}$ had no significant effects on the cell viability $(P>$ $0.05)$. However, concentrations higher than that amount will be toxic to RAW 264.7 cells (data not shown). With this result, we chose concentrations of EECP up to $20 \mu \mathrm{g} / \mathrm{mL}$ in the subsequent experiments.

\subsection{Effects of EECP on the Production of NO, IL-1 $1 \beta$ and IL-6 in} LPS-Stimulated RAW 264.7 Cells. Figures 2(a), 2(b), and 2(c) show the effects of EECP on NO, IL- $1 \beta$ and IL-6 production in LPS-stimulated RAW 264.7 cells. Our previous data found Chinese propolis exhibited good anti-inflammatory effects in vivo and EECP could inhibit the production of some inflammation-related cytokines [12]. So we first investigated effects of EECP on the production of some proinflammatory cytokines, including IL- $1 \beta$, and IL- 6 as well as the NO generation in LPS-stimulated RAW 264.7 cells. ELISA assays were used to determinate the proinflammatory cytokines and Greiss' reaction was used to estimate the NO generation. In the absence of LPS, very low amounts of NO and those two proinflammatory cytokines were detected in the culture supernatants of RAW 264.7 cells. Upon stimulation with LPS $(1 \mu \mathrm{g} / \mathrm{mL})$, NO production was markedly increased (Figure $2(a))$. We also found significant increases of IL-1 $\beta$ and IL- 6 in the presence of LPS-stimulation (Figures $2(\mathrm{~b})$ and 2(c)). However, pretreatment with EECP for $1 \mathrm{~h}$ could significantly reduce the production of NO, IL- $1 \beta$ and IL- 6 in a dosedependent manner (Figures 2(a) to 2(c)).

3.4. Effects of EECP on iNOS, IL-1 $\beta$ and IL-6 mRNA Expression in LPS-Stimulated RAW 264.7 Cells. Figure 3 shows the effects of EECP on mRNA expression of iNOS, 


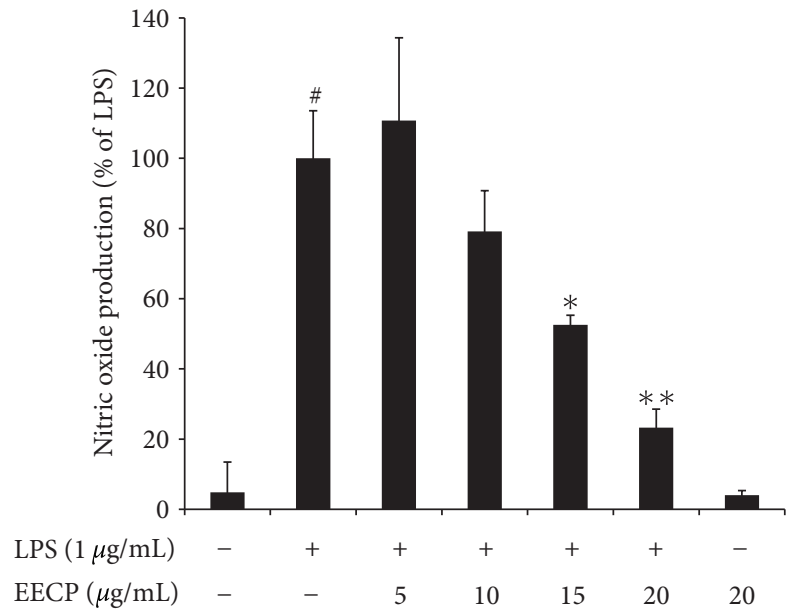

(a)

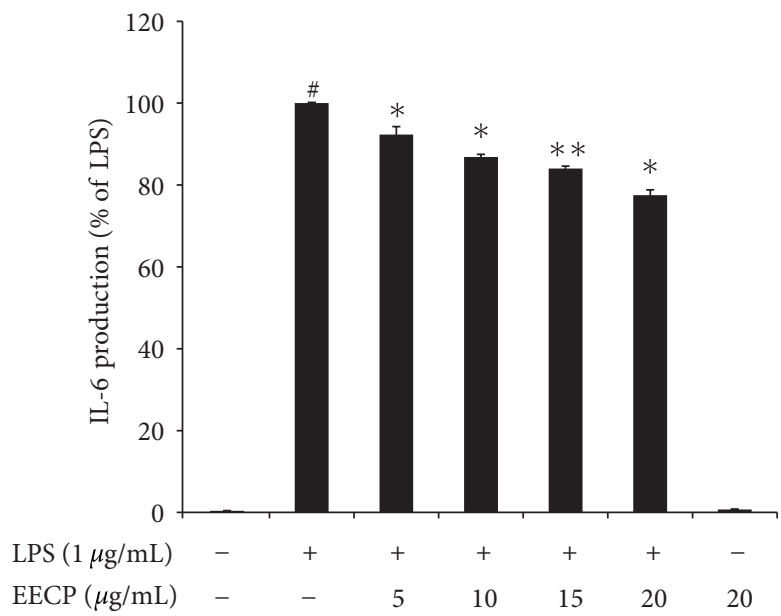

(c)

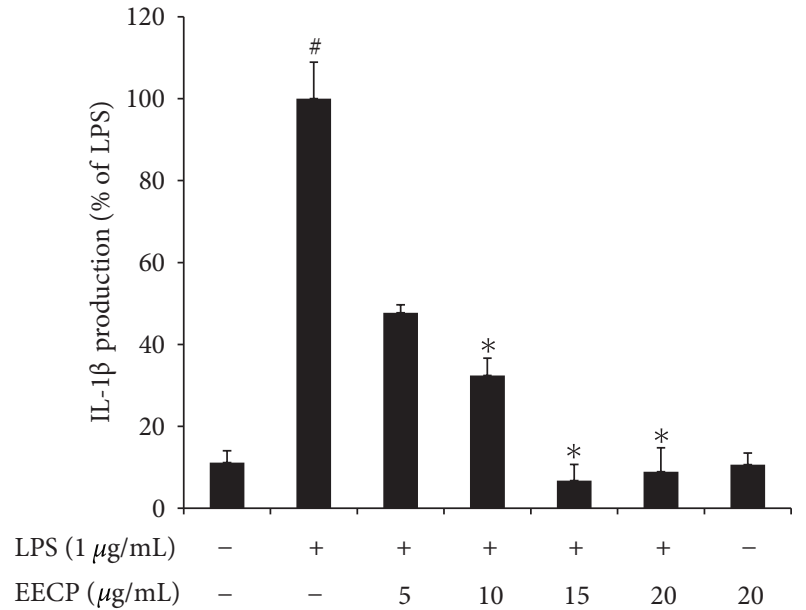

(b)

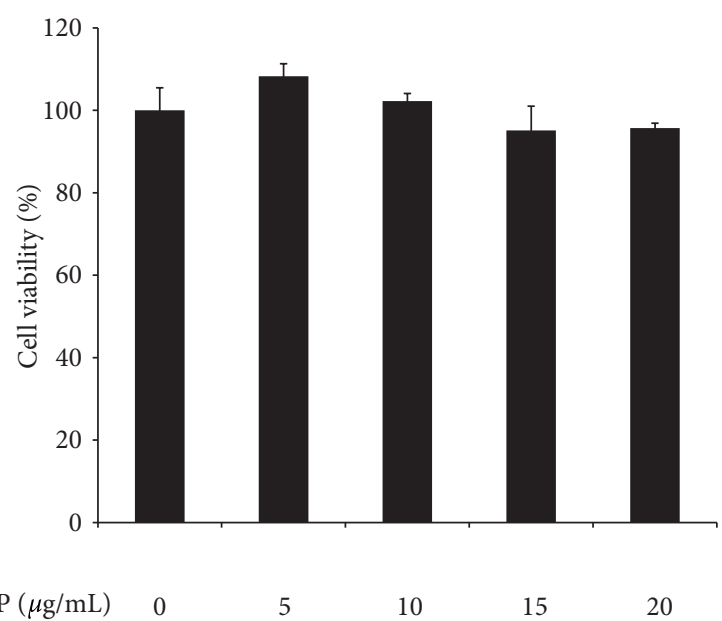

(d)

FIGURE 2: Effects of EECP on LPS-induced NO, IL-1 $\beta$, and IL-6 production and cell viability in RAW 264.7 cells. (a-c) Cells were pretreated with/without indicated concentrations of EECP for $1 \mathrm{~h}$ then stimulated with LPS $(1 \mu \mathrm{g} / \mathrm{mL})$ for $18 \mathrm{~h}$. Control values were obtained in the absence of LPS or EECP. The values are presented as percentages of NO (a), IL-1 $\beta$ (b), and IL-6 (c) comparing with LPS-treated cells, respectively. (d) RAW 264.7 cells were treated with indicated concentrations of EECP $(0-20 \mu \mathrm{g} / \mathrm{mL})$ for $24 \mathrm{~h}$, and the results are expressed by percentages of surviving cells over control cells (no addition of EECP) using MTT assays. The data are the means \pm SDs for three independent experiments. Individual groups were compared using Student's $t$-test $\left({ }^{*} P<0.05,{ }^{* *} P<0.01\right.$ compared with the LPS group; ${ }^{\#} P<0.05$ compared with untreated group).

IL-1 $\beta$, and IL-6 in LPS-stimulated RAW 264.7 cells. Timeand dose-effect of EECP on the mRNA expression of iNOS, IL- $1 \beta$, and IL- 6 was measured in RAW 264.7 cells stimulated with LPS in the presence or absence of EECP using quantitative real-time reverse transcriptase polymerase chain reaction (qRT-PCR). As expected from several previous studies, upon stimulation with LPS, mRNA expressions of three inflammatory-related genes in RAW 264.7 cells were upregulated strongly $[20,21]$. The mRNA expression reached a peak level at about $6 \mathrm{~h}$ for IL- $1 \beta$ and IL-6, $9 \mathrm{~h}$ for iNOS. Pretreatment of EECP at $15 \mu \mathrm{g} / \mathrm{mL}$ could block the expression of these mRNAs at all of indicated time points (Figure 3(a)). We also observed that pretreatment of various concentrations of EECP on the inhibition of LPS-induced mRNA levels of those three genes is dose-dependent (Figure 3(b)).

3.5. Effects of EECP on the Degradation and Phosphorylation of $I \kappa B-\alpha$ in LPS-Stimulated RAW 264.7 Cells. Figure 4 indicates total and phosphorylation protein expression levels of $\mathrm{I} \kappa \mathrm{B}-\alpha$ in the cytoplasm. In order to further clarify the molecular mechanisms underlying EECP-mediated suppressive effects of those inflammation-related genes, we next used Western blot analysis with specific antibodies to characterize effects of EECP on LPS-induced $\mathrm{I} \kappa \mathrm{B} \alpha$ phosphorylation and degradation, which were regarded as two symbolic events in the activation of NF- $\kappa \mathrm{B}$ signal transduction. A time-course 

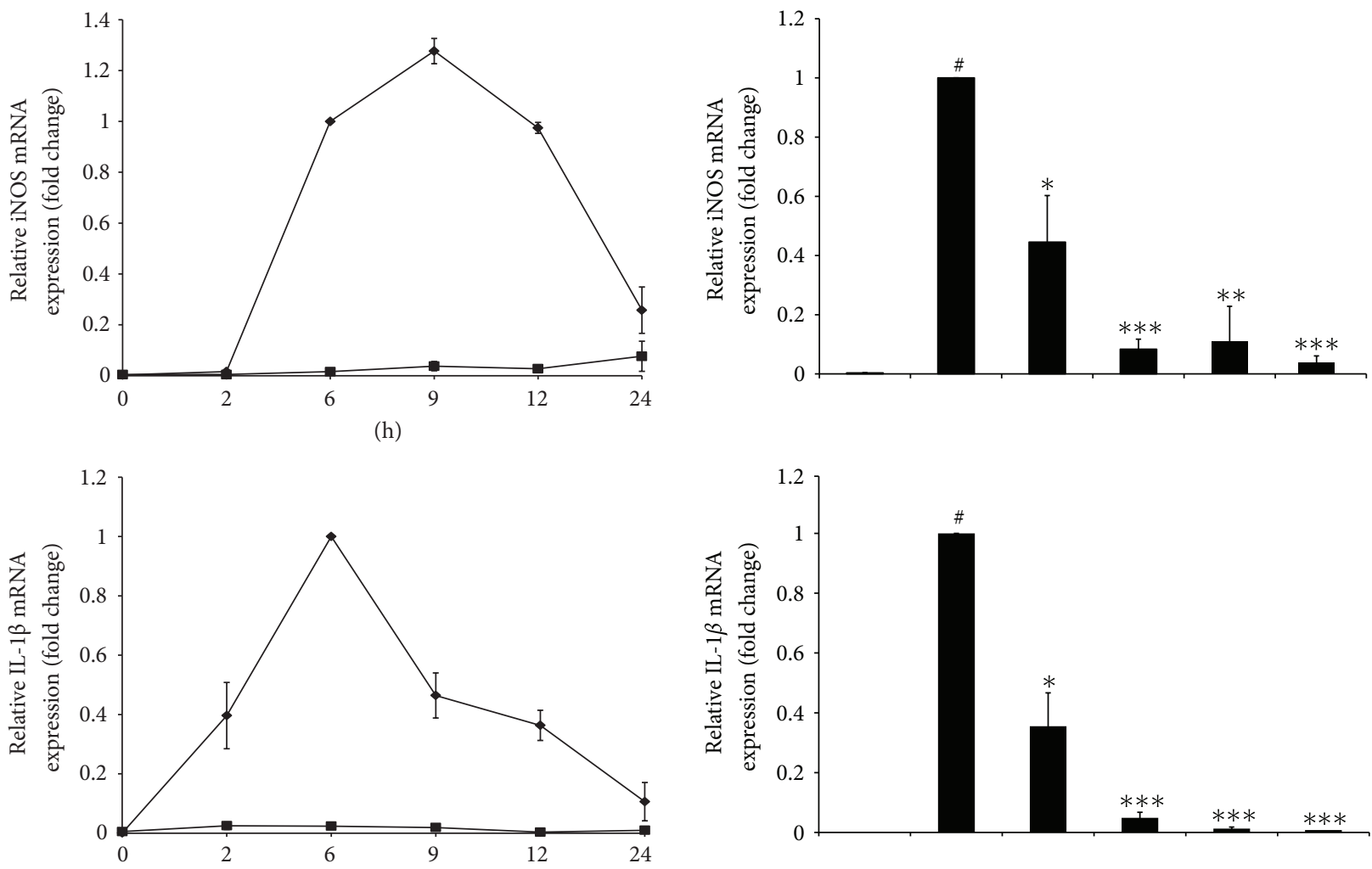

(h)

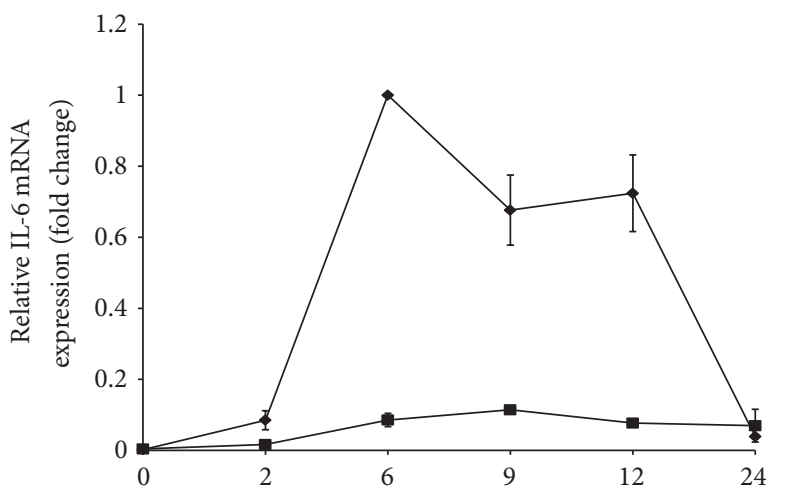

(h)

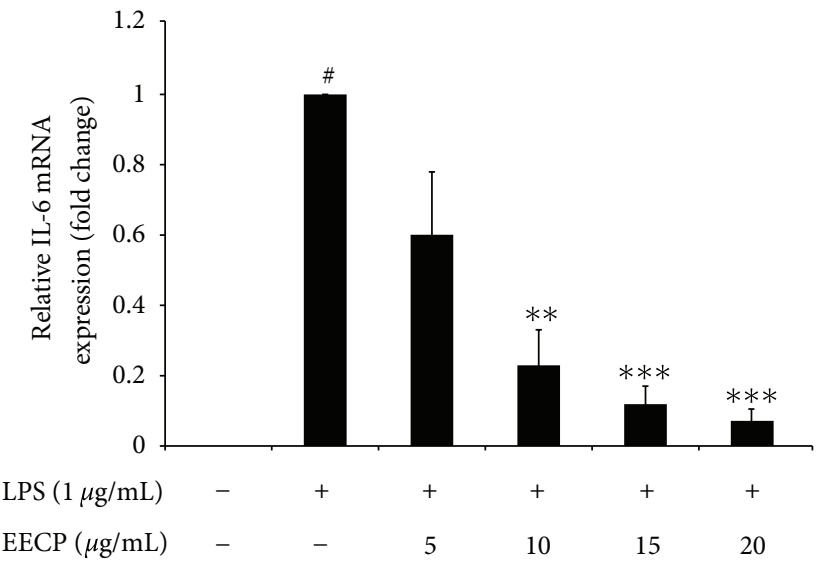

$\rightarrow$ LPS

$\operatorname{EECP}(\mu \mathrm{g} / \mathrm{mL})$

(b)

FIGURE 3: Effects of EECP on iNOS, IL-1 $\beta$ and IL-6 mRNA expression in LPS-stimulated RAW 264.7 cells. Dose-dependent (a) and timecourse (b) inhibitory effect of EECP were measured on LPS-induced iNOS IL- $1 \beta$ and IL- 6 mRNA expression in RAW 264.7 cells were measured using qRT-PCR, as described in Section 2. (a) Cells were pretreated with EECP $(15 \mu \mathrm{g} / \mathrm{mL})$ or not for $1 \mathrm{~h}$, then stimulated with LPS $(1 \mu \mathrm{g} / \mathrm{mL})$ at various time points. (b) Dose-effect relationship was measured after $6 \mathrm{~h}$ stimulation with LPS $(1 \mu \mathrm{g} / \mathrm{mL})$. Results are expressed as a target gene expressions ratio comparing with the LPS-treated group. The data are the means \pm SDs for three independent experiments. Individual groups were compared using student's $t$-test $\left({ }^{*} P<0.05,{ }^{* *} P<0.01,{ }^{* * *} P<0.001\right.$ compared with the LPS group; ${ }^{\#} P<0.05$ compared with untreated group).

experiment showed that the phosphorylation of $\mathrm{I} \kappa \mathrm{B} \alpha$ was increased from $15 \mathrm{~min}$ after LPS treatment and application of $15 \mu \mathrm{g} / \mathrm{mL}$ EECP attenuated LPS-induced phosphorylation of $\mathrm{I} \kappa \mathrm{B} \alpha$. In contrast, comparing with LPS treated cells, the degradation of $\mathrm{I} \kappa \mathrm{B} \alpha$ seemed was unaffected by combination of EECP and LPS (Figures 4(a) and 4(b)). A dosecourse experiment showed EECP at a concentration of 10 to $20 \mu \mathrm{g} / \mathrm{mL}$ could block the LPS-induced phosphorylation of 


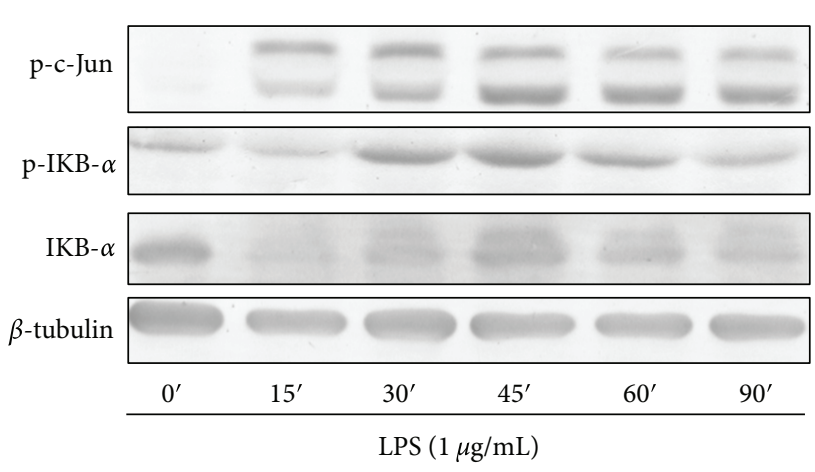

(a)

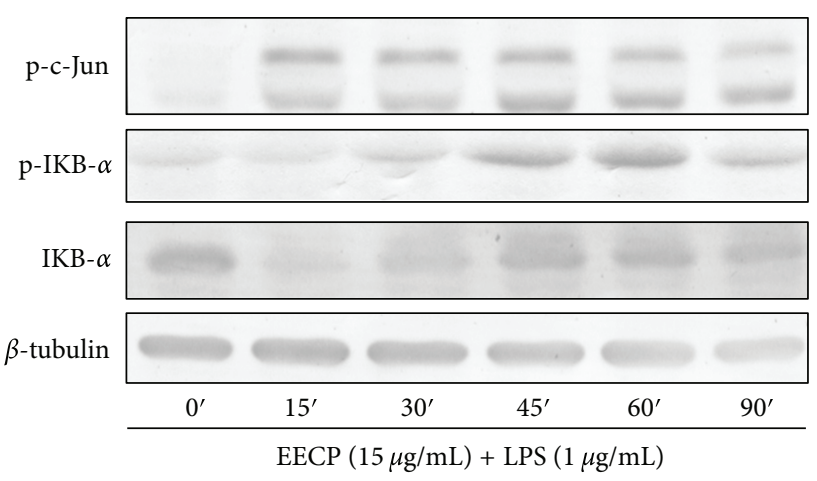

(b)

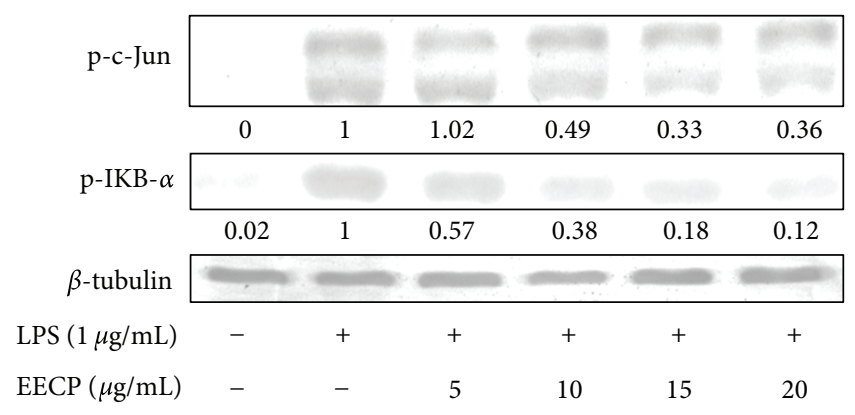

(c)

FIGURE 4: Effects of EECP on the phosphorylation of I $\kappa$ B- $\alpha$ and AP-1 in LPS-stimulated RAW 264.7 cells. (a) RAW 264.7 cells were stimulated with LPS $(1 \mu \mathrm{g} / \mathrm{mL})$ for indicated times or (b) were pretreated with EECP $(15 \mu \mathrm{g} / \mathrm{mL})$ for $1 \mathrm{~h}$ then stimulated with LPS $(1 \mu \mathrm{g} / \mathrm{mL})$ for indicated times. (c) RAW 264.7 cells were pretreated or not with indicated concentrations of EECP for $1 \mathrm{~h}$ then were stimulated with LPS $(1 \mu \mathrm{g} / \mathrm{mL})$ for $30 \mathrm{~min}$. Whole cell lysates were analyzed by Western blotting analysis using specific antibodies. The relative expression of proteins was quantified using Quantity One software comparing with $\beta$-tubulin. Data shown are the representative of three independent experiments with similar results.

I $\kappa \mathrm{B} \alpha$ (Figure $4(\mathrm{~b}))$ but has no significant effect on preventing the degradation of $\mathrm{I} \kappa \mathrm{B} \alpha$ (data not shown).

3.6. Effect of EECP on the Phosphorylation of AP-1 in LPSStimulated RAW 264.7 Cells. Figure 4 also shows the phosphorylation levels of c-Jun, a major component of AP-1 in LPS-stimulated RAW 264.7 cells. Previous studies have found that many inflammatory mediators, such as iNOS, IL- $1 \beta$ and IL- 6 were regulated not only by NF- $\kappa$ B but also by AP- 1 , another important transcription factor involved in MAPK signaling pathways. Following LPS stimulation, the AP-1 heterodimer, c-Jun and c-Fos translocated into the nucleus, leading to the transcription of several inflammatory-related genes [4]. To further explore whether AP-1 is involved in the inhibition of those inflammatory factors by EECP, we examined time- and dose-effect of EECP on the phosphorylation of c-Jun in LPS-stimulated RAW 264.7 cells. After LPS stimulation, the phosphorylation level of c-Jun was dramatically increased from $15 \mathrm{~min}$ and at a peak level at about $30 \mathrm{~min}$ (Figure 4(a)). Pretreatment with $15 \mu \mathrm{g} / \mathrm{mL}$ of EECP could postpone c-Jun's phosphorylation at the peak level at about 60 to $90 \mathrm{~min}$ (Figure 4(b)). EECP could also suppress LPS-induced phosphorylation of c-Jun (AP-1) in a dose-dependent manner (Figure 4(c)).
3.7. Effect of EECP on NF- $\kappa B$ Activation in TNF- $\alpha$ Treated $H E K 293 T$ Cells. Figure 5 shows effect of EECP on NF- $\kappa \mathrm{B}$ activation in TNF- $\alpha$ treated HEK 293 T cells. Paulino et al. previously demonstrated that ethanol extracts of Brazilian green propolis exerted a strong suppressive effect on NF- $\kappa \mathrm{B}$ activation using a reporter assay system with an $\mathrm{IC}_{50}$ value of $200 \mu \mathrm{g} / \mathrm{mL}$ [13]. However, botanical origins and chemical compositions between Brazilian green propolis and Chinese propolis are quite different, so we evaluated the effect of EECP on the NF- $\kappa \mathrm{B}$ activation using a reporter assay system in TNF- $\alpha$ treated HEK 293 T cells. As shown in Figure 5, the up-regulation of the relative luciferase activity stimulated by TNF- $\alpha(10 \mathrm{ng} / \mathrm{mL})$ was significantly $(P<0.05)$ decreased by EECP (10 to $20 \mu \mathrm{g} / \mathrm{mL}$ ).

\section{Discussion}

The present study was undertaken to elucidate the mechanisms underlying the anti-inflammatory and immunomodulating effects of a flavonoid-rich ethanol extract from Chinese propolis (poplar type), which has been widely used in folk medicine and health food among China and all over the world [5]. Indeed, chemical constituents of propolis vary widely with respect to their geographic regions and plant 


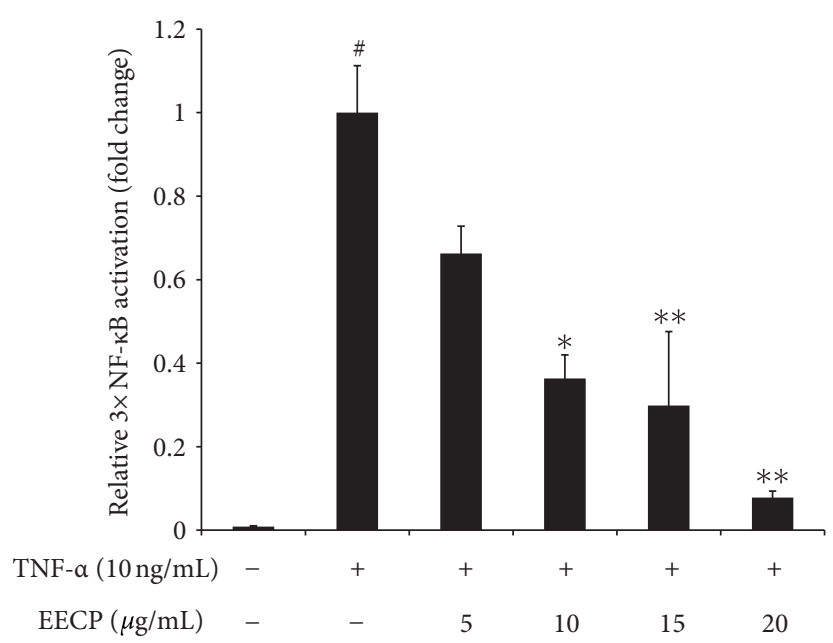

FIgURE 5: Effect of EECP on NF- $\kappa$ B activation in TNF- $\alpha$ treated HEK 293T cells. HEK 293T cells were transiently transfected with firefly luciferase reporter plasmid (pGL4.2-3×NF-KB-Luc) and luciferase reporter plasmid (pRL-TK) for $24 \mathrm{~h}$. Then cells were pretreated with an increasing concentrations of EECP $(0-20 \mu \mathrm{g} / \mathrm{mL})$ in the presence of TNF- $\alpha(10 \mathrm{ng} / \mathrm{mL})$. Unstimulated cells were used as a negative control. Luciferase activity was normalized to tk-Renilla luciferase activity and results are expressed by the percentage of TNF- $\alpha$ treated group. Data represent the mean $\pm \mathrm{SD}$ of three independent experiments. Individual groups were compared using student's $t$-test $\left({ }^{*} P<0.05,{ }^{* *} P<0.01\right.$, ${ }^{* * *} P<0.001$ compared with the LPS group; ${ }^{\#} P<0.05$ compared with untreated group).

sources. However, biological activities of propolis always present. As far as Chinese propolis, the raw material we used in this study is origin from Shandong province which is located in North China and the main botanical source of this type of propolis is well known as poplar (Populus sp.) [22]. Based on previous studies, we first chose eight most frequently-presented flavonoids in poplar type propolis, including rutin, myricetin, quercetin, kaempferol, apigenin, pinocembrin, chrysin, and galangin to analyzed their relative amount in EECP $[14,23]$. The chromatographic profile of EECP meets the characters of the poplar-type propolis, which is marked by high amounts of flavonoids (including flavones, flavonols, flavanones and dihydroflavonols) and other phenolics (mainly cinnamic acids and their esters) [24].

It is known that macrophage plays an important role in the immune system as well as the inflammation process. LPS-stimulated macrophages can secrete a variety of inflammatory mediators, including NO, IL-1 $\beta$, and IL-6. Overproduction of these mediators will break the immune homeostasis and cause several inflammatory diseases, including septic shock, arteriosclerosis, and cancer. To continue our work to clarify the mechanisms underlying the antiinflammatory effects of EECP, we first chose LPS-stimulated RAW 264.7 cells as an in vitro model to evaluate the effects of ethanol extract from Chinese propolis (poplar type) on the production and mRNA expression of those inflammatory mediators. Our results showed that LPS-stimulation strongly up-regulated the production and secretion of NO, IL- $1 \beta$ and IL-6. NO is one ubiquitous cellular mediator, which is produced by iNOS, which can generate and modify intracellular signals. During the pathological process, overproduction of NO is harmful [25]. Parallel to previous study, we also found that EECP could significantly reduce NO production and iNOS mRNA expression in activated macrophages regardless of the geographic locations of the samples used in these experiments $[26,27]$. Meanwhile, in activated macrophages, IL- $1 \beta$ and IL- 6 are known as two important proinflammatory cytokines which can cause the aggravation of inflammation and induce tissue damages [28]. Previous study using LPSactivated J744A.1 macrophages model found ethanol extract of propolis could significantly suppress the production and expression of IL- $1 \beta$ in a dose-dependent manner. Recently, effects of propolis and its isolated compounds, on some cytokines production (IL-1 $\beta$, IL-6, and IL-10) has been investigated. Bachiega et al. found that ethanol extracts of propolis (collected in south area of Brazil) could suppress the cytokines production induced by LPS both before and after its addition [29]. In the present study, we also found EECP could suppress the production of IL- $1 \beta$ and IL-6. Meanwhile, using qRT-PCR we found that EECP on the inhibition of LPS-induced mRNA levels of iNOS, IL- $1 \beta$, and IL- 6 is time- and dose-dependent, indicating that EECP exerts a suppressive effect against the inflammation-related genes at transcriptional level.

Since the transcriptional upregulation of inflammatory mediators is reported to be due to some redox sensitive transcription factors such as NF- $\kappa \mathrm{B}$ and $\mathrm{AP}-1$ [2, 3], we hypothesize that EECP could be involved in the modulation of these transcription factors. In LPS-induced models, activated macrophages produce numerous proinflammatory mediators most of which is regulated by NF- $\kappa \mathrm{B}$ transcription factor and this pivotal signaling pathway mediating inflammatory responses has been well-established by many previous reports $[18,28]$. Similar to previous studies, our results found that LPS-stimulation led to a rapid phosphorylation and degradation of $\mathrm{I} \kappa \mathrm{B} \alpha$ that peaked at $30 \mathrm{~min}$. EECP alone could not induce any change of $\mathrm{I} \kappa \mathrm{B} \alpha$ in resting RAW 264.7 cells (data not shown), but it had a strong inhibition effect 
on phosphorylation of $\mathrm{I} \kappa \mathrm{B} \alpha$. However, effect of EECP on preventing the degradation of $\mathrm{I} \kappa \mathrm{B} \alpha$ is not very obvious. Interestingly, NF- $\kappa \mathrm{B}$ reporter assay result showed that EECP also displayed a strong suppressive effect on the activation of NF- $\kappa$ B in TNF- $\alpha$ activated HEK 293T cells, regardless of the geographic location and the propolis samples used [13]. Further studies should focus on the effects of some other essential upstream or downstream events associated with NF- $\kappa \mathrm{B}$ cascade, such as the phosphorylation of $\mathrm{I} \kappa \mathrm{B} \alpha$ kinase (IKK) or the translocation of NF- $\kappa \mathrm{B}$. On the other hand, AP-1 is another important transcriptional factor during the transcription and production of some inflammatory mediators. Many inflammatory-related genes not only contain $\kappa \mathrm{B}$ sites but also has AP-1 binding sites in their promoters. However, effect of propolis extracts on the transcription of AP-1 is still elusive. Upon stimulation with $1 \mu \mathrm{g} / \mathrm{mL}$ LPS, the phosphorylation of AP-1 reached a peak level at 30-45 min, then decreased. This result is a slight inconformity with previous study. Shan et al. found the phosphorylation of AP1 reached a peak level after stimulation with LPS for $1 \mathrm{~h}$ [20]. We considered that this inconformity is acceptable, for the LPS amount we used is quite different; they used $100 \mathrm{ng} / \mathrm{mL}$ instead of $1 \mu \mathrm{g} / \mathrm{mL}$ LPS we used. High amounts of LPS used seem promoted the phosphorylation and transcription of AP-1. Even so, pretreated with EECP before the stimulation displayed a potential suppressing effect on the phosphorylation of AP-1, gave us another explanation to the attenuation of those proinflammatory cytokines production by EECP pretreatment before the LPS stimulation.

Although numerous studies reported that propolis has a wide spectrum of pharmacological activities, we should not ignore the main constituent of propolis from different geographic locations is quite different. Various factors, such as plant resources, collecting seasons, species of bees, and the solvents used in extraction, will influence the chemical constituent of propolis $[22,24]$. So it is necessary to distinguish between specific propolis types and its corresponding compositions. In contrast with other types of propolis, such as Brazilian green propolis, birch type propolis, or red propolis, the samples we used is originated from Shandong, and only can be seen as a representative of poplar type propolis of Northern China. The phytochemistry analysis also found that it contains multiple kinds of flavonoids at a relatively high amount. Among them we found that pinocembrin (84.6 $\pm 0.2 \mathrm{mg} / \mathrm{g}$ of the extract), chrysin $(33.5 \pm 0.1 \mathrm{mg} / \mathrm{g}$ of the extract) and galangin $(29.1 \pm 0.2 \mathrm{mg} / \mathrm{g}$ of the extract $)$ are three of the most abundant flavonoids presented in EECP. Previous studies have confirmed their effects on activated RAW 264.7 macrophages [30]. Yu et al. found that pinocembrin could inhibit LPS-stimulated nitric oxide (NO) and prostaglandin E2 (PGE2) production in RAW 264.7 cells by blocking the activation of NF- $\kappa$ B [31]. Similar effects were also observed using chrysin [32]. It has also reported chrysin and galangin could suppress the IL- $1 \beta$ gene expression in activated RAW 264.7 macrophages via inhibiting the gene transcription [33].

We also noticed that some previous reports found that propolis could activate the macrophage and induce $\mathrm{NO}$ and TNF- $\alpha$ production [34]. Some in vitro and in vivo assays also demonstrated that propolis can modulate the action of murine peritoneal macrophages and increase their resistance against some microbes $[21,35]$. It is worth noting that the mechanisms seem to differ by the types of propolis used, the extraction method used, even the cell-line and the stimulus. Many isolated constituents presented in propolis have been found with properties of immunoregulation. For example, some constituents in propolis may exert an immunosuppressive effect, such as caffeic acid phenyl ester (CAPE), artepillin C (3,5-diprenyl-4-hydroxycinnamic acid). CAPE can inhibit the induction of cytokines, as well as iNOS and cyclooxygenase (COX)-2 expression, after in vitro LPS stimulation [36]. CAPE is also a potent inhibitor of T-cellreceptor-mediated $\mathrm{T}$ cell proliferation and often acts as an inhibitor of NF- $\kappa \mathrm{B}$ [37]. Paulino et al. found that artepillin C could suppress macrophage activation and block the activity of NF- $\kappa \mathrm{B}$ [38]. However, some other constituents presented in propolis were reported with immunostimulatory effects, including cinnamic and coumaric acids [29, 39]. So we speculate that the effects of various kinds of propolis may also attribute to their synergic effect among various compounds. Some of those constituents may act both cooperatively and antagonistically. Total effect of propolis, without any doubt, depends on the composition of those biologically active ingredients and their concentrations.

In conclusion, our study confirmed the in-vitro antiinflammatory effects of a flavonoid-rich ethanol extract from Chinese propolis (poplar type). We studied the major constituents of EECP and eight flavonoids have been identified. We also observed that EECP could block the production of NO, IL-1 $\beta$, and IL-6 in LPS-stimulated RAW 264.7 cells. EECP was able to regulate the mRNA expression of iNOS, IL$1 \beta$, and IL- 6 in a time- and dose-dependent manner. These effects seem to be mediated, at least in part, by inhibiting the phosphorylation of $\mathrm{I} \kappa \mathrm{B} \alpha$ and $\mathrm{AP}-1$. We also found EECP could block NF- $\kappa$ B activation in TNF- $\alpha$ stimulated HEK 293T cells. Nevertheless, we still cannot rule out other possible mechanisms may be involved. Our study gives a new insight for understanding the mechanisms involved in anti-inflammatory effect by Chinese propolis as well as provides some references for using propolis in alternative and complementary therapies in the future.

\section{Abbreviations}

EECP: Ethanol extract of Chinese propolis

HPLC: High performance liquid chromatography

NO: $\quad$ Nitric oxide

IL: Interleukin

iNOS: Inducible form of nitric oxide synthase

$\mathrm{I} \kappa \mathrm{B}$ : Inhibitor of $\kappa \mathrm{B}$ binding protein

NF- $\kappa$ B: Nuclear factor kappa B

AP-1: Activator protein-1

LPS: Lipopolysaccharide

TNF- $\alpha$ : Tumor necrosis factor $\alpha$

PC-PLC: Phosphatidylcholine-specific phospholipase C

ROS: $\quad$ Reactive oxygen species

PGE2: Prostaglandin E2

CAPE: Caffeic acid phenyl ester. 


\section{Acknowledgments}

The authors wish to thank Professor Zongping Xia from Life Sciences Institute, Zhejiang University, for his excellent technical support and generously providing cell lines, antibodies, and other reagents. They also acknowledge Professor Hongxiang Sun from College of Animal Sciences, Zhejiang University, for his valuable suggestions during the experiments and in preparation of this paper. This work was supported by the Grant from the National Natural Science Foundation of China (no. 31272512), the Modern Agroindustry Technology Research System from the Ministry of Agriculture of China (CARS-45), and Shandong Provincial Natural Science Foundation of China (ZQ2012CQ003).

\section{References}

[1] J. A. Rankin, "Biological mediators of acute inflammation," AACN Clinical Issues, vol. 15, no. 1, pp. 3-17, 2004.

[2] C. S. Chang, H. L. Sun, C. K. Lii, H. W. Chen, P. Y. Chen, and K. L. Liu, "Gamma-linolenic acid inhibits inflammatory responses by regulating $\mathrm{nf}-\kappa \mathrm{B}$ and $\mathrm{AP}-1$ activation in lipopolysaccharideinduced RAW 264.7 macrophages," Inflammation, vol. 33, no. 1, pp. 46-57, 2010.

[3] S. Vallabhapurapu and M. Karin, "Regulation and function of $\mathrm{NF}-\kappa \mathrm{B}$ transcription factors in the immune system," Annual Review of Immunology, vol. 27, pp. 693-733, 2009.

[4] G. J. Wu, T. L. Chen, Y. F. Ueng, and R. M. Chen, "Ketamine inhibits tumor necrosis factor- $\alpha$ and interleukin- 6 gene expressions in lipopolysaccharide-stimulated macrophages through suppression of toll-like receptor 4-mediated c-Jun N-terminal kinase phosphorylation and activator protein-1 activation," Toxicology and Applied Pharmacology, vol. 228, no. 1, pp. 105-113, 2008.

[5] G. Chan, K. W. Cheung, and D. Sze, "The immunomodulatory and anticancer properties of propolis," Clinical Reviews in Allergy and Immunology. In press.

[6] G. M. Sulaiman, K. W. A. Sammarrae, A. H. Ad'hiah et al., "Chemical characterization of iraqi propolis samples and assessing their antioxidant potentials," Food and Chemical Toxicology, vol. 49, no. 9, pp. 2415-2421, 2011.

[7] E. Mascheroni, V. Guillard, F. Nalin, L. Mora, and L. Piergiovanni, "Diffusivity of propolis compounds in Polylactic acid polymer for the development of anti-microbial packaging films," Journal of Food Engineering, vol. 98, no. 3, pp. 294-301, 2010.

[8] E. Szliszka, G. Zydowicz, B. Janoszka, C. Dobosz, G. KowalczykZiomek, and W. Krol, "Ethanolic extract of Brazilian green propolis sensitizes prostate cancer cells to TRAIL-induced apoptosis," International Journal of Oncology, vol. 38, no. 4, pp. 941-953, 2011.

[9] S. Nolkemper, J. Reichling, K. H. Sensch, and P. Schnitzler, "Mechanism of herpes simplex virus type 2 suppression by propolis extracts," Phytomedicine, vol. 17, no. 2, pp. 132-138, 2010.

[10] M. P. de Barros, J. P. B. Sousa, J. K. Bastos, and S. F. de Andrade, "Effect of Brazilian green propolis on experimental gastric ulcers in rats," Journal of Ethnopharmacology, vol. 110, no. 3, pp. 567-571, 2007.

[11] J. M. Sforcin, "Propolis and the immune system: a review," Journal of Ethnopharmacology, vol. 113, no. 1, pp. 1-14, 2007.
[12] W. Zhu, Y. H. Li, M. L. Chen, and F. L. Hu, "Protective effects of Chinese and Brazilian propolis treatment against hepatorenal lesion in diabetic rats," Human and Experimental Toxicology, vol. 30, no. 9, pp. 1246-1255, 2011.

[13] N. Paulino, C. Teixeira, R. Martins et al., "Evaluation of the analgesic and anti-inflammatory effects of a Brazilian green propolis," Planta Medica, vol. 72, no. 10, pp. 899-906, 2006.

[14] H. Izuta, M. Shimazawa, S. Tazawa, Y. Araki, S. Mishima, and H. Hara, "Protective effects of Chinese propolis and its component, chrysin, against neuronal cell death via inhibition of mitochondrial apoptosis pathway in SH-SY5Y cells," Journal of Agricultural and Food Chemistry, vol. 56, no. 19, pp. 8944-8953, 2008.

[15] F. Hu, H. R. Hepburn, Y. Li, M. Chen, S. E. Radloff, and S. Daya, "Effects of ethanol and water extracts of propolis (bee glue) on acute inflammatory animal models," Journal of Ethnopharmacology, vol. 100, no. 3, pp. 276-283, 2005.

[16] F. Hu, H. Xuan, R. Zhu, and Y. Li, "Inhibitory effect of chinese propolis on phosphatidylcholine-specific phospholipase C activity in vascular endothelial cells," Evidence-Based Complementary and Alternative Medicine, vol. 2011, Article ID 985278, 8 pages, 2011.

[17] D. A. Scudiero, R. H. Shoemaker, K. D. Paull et al., "Evaluation of a soluble tetrazolium/formazan assay for cell growth and drug sensitivity in culture using human and other tumor cell lines," Cancer Research, vol. 48, no. 17, pp. 4827-4833, 1988.

[18] C. Xie, J. Kang, Z. Li et al., "The açaí flavonoid velutin is a potent anti-inflammatory agent: blockade of LPS-mediated TNF- $\alpha$ and IL- 6 production through inhibiting NF- $\kappa$ B activation and MAPK pathway," Journal of Nutritional Biochemistry, vol. 23, no. 9, pp. 1184-1191, 2012.

[19] J. Zhou, Y. Li, J. Zhao, X. Xue, L. Wu, and F. Chen, "Geographical traceability of propolis by high-performance liquidchromatography fingerprints," Food Chemistry, vol. 108, no. 2, pp. 749-759, 2008.

[20] J. Shan, J. Fu, Z. Zhao et al., "Chlorogenic acid inhibits lipopolysaccharide-induced cyclooxygenase- 2 expression in RAW264.7 cells through suppressing NF- $\kappa$ B and JNK/AP-1 activation," International Immunopharmacology, vol. 9, no. 9, pp. 1042-1048, 2009.

[21] J. M. Murad, S. A. Calvi, A. M. V. C. Soares, V. Bankova, and J. M. Sforcin, "Effects of propolis from Brazil and Bulgaria on fungicidal activity of macrophages against Paracoccidioides brasiliensis," Journal of Ethnopharmacology, vol. 79, no. 3, pp. 331-334, 2002.

[22] V. Bankova, "Chemical diversity of propolis and the problem of standardization," Journal of Ethnopharmacology, vol. 100, no. 12, pp. 114-117, 2005.

[23] M. R. Ahn, S. Kumazawa, Y. Usui et al., "Antioxidant activity and constituents of propolis collected in various areas of China," Food Chemistry, vol. 101, no. 4, pp. 1383-1392, 2007.

[24] M. P. Popova, V. S. Bankova, S. Bogdanov et al., "Chemical characteristics of poplar type propolis of different geographic origin," Apidologie, vol. 38, no. 3, pp. 306-311, 2007.

[25] T. J. Guzik, R. Korbut, and T. Adamek-Guzik, "Nitric oxide and superoxide in inflammation and immune regulation," Journal of Physiology and Pharmacology, vol. 54, no. 4, pp. 469-487, 2003.

[26] M. Blonska, J. Bronikowska, G. Pietsz, Z. P. Czuba, S. Scheller, and W. Krol, "Effects of ethanol extract of propolis (EEP) and its flavones on inducible gene expression in J774A.1 macrophages," Journal of Ethnopharmacology, vol. 91, no. 1, pp. 25-30, 2004. 
[27] Y. S. Song, E. H. Park, G. M. Hur, Y. S. Ryu, Y. M. Kim, and C. Jin, "Ethanol extract of propolis inhibits nitric oxide synthase gene expression and enzyme activity," Journal of Ethnopharmacology, vol. 80, no. 2-3, pp. 155-161, 2002.

[28] X. Zhang, H. Xiong, and L. Liu, "Effects of taraxasterol on inflammatory responses in lipopolysaccharide- induced RAW 264. 7 macrophages," Journal of Ethnopharmacology, vol. 141, no. 1, pp. 206-211, 2012.

[29] T. F. Bachiega, C. L. Orsatti, A. C. Pagliarone, and J. M. Sforcin, "The effects of propolis and its isolated compounds on cytokine production by murine macrophages," Phytotherapy Research, vol. 26, no. 9, pp. 1308-1313, 2012.

[30] M. Hämäläinen, R. Nieminen, P. Vuorela, M. Heinonen, and E. Moilanen, "Anti-inflammatory effects of flavonoids: genistein, kaempferol, quercetin, and daidzein inhibit STAT-1 and NF$\kappa \mathrm{B}$ activations, whereas flavone, isorhamnetin, naringenin, and pelargonidin inhibit only NF- $\kappa \mathrm{B}$ activation along with their inhibitory effect on iNOS expression and NO production in activated macrophages," Mediators of Inflammation, vol. 2007, Article ID 45673, 10 pages, 2007.

[31] Y. S. Yu, C. L. Hsu, and Y. Gow-Chin, "Anti-inflammatory effects of the roots of Alpinia pricei hayata and its phenolic compounds," Journal of Agricultural and Food Chemistry, vol. 57, no. 17, pp. 7673-7680, 2009.

[32] G. K. Harris, Y. Qian, S. S. Leonard, D. C. Sbarra, and X. Shi, "Luteolin and chrysin differentially inhibit cyclooxygenase-2 expression and scavenge reactive oxygen species but similarly inhibit prostaglandin-E 2 formation in RAW 264.7 cells," Journal of Nutrition, vol. 136, no. 6, pp. 1517-1521, 2006.

[33] M. Blonska, Z. P. Czuba, and W. Krol, "Effect of flavone derivatives on interleukin- $1 \beta$ (IL-1 $\beta$ ) mRNA expression and IL- $1 \beta$ protein synthesis in stimulated RAW 264.7 macrophages," Scandinavian Journal of Immunology, vol. 57, no. 2, pp. 162-166, 2003.

[34] S. Han, K. H. Sung, D. Yim et al., "Activation of murine macrophage cell line RAW 264.7 by Korean propolis," Archives of Pharmacal Research, vol. 25, no. 6, pp. 895-902, 2002.

[35] R. O. Orsi, J. M. Sforcin, S. R. C. Funari, and V. Bankova, "Effects of Brazilian and Bulgarian propolis on bactericidal activity of macrophages against Salmonella Typhimurium," International Immunopharmacology, vol. 5, no. 2, pp. 359-368, 2005.

[36] W. K. Jung, I. Choi, D. Y. Lee et al., "Caffeic acid phenethyl ester protects mice from lethal endotoxin shock and inhibits lipopolysaccharide-induced cyclooxygenase- 2 and inducible nitric oxide synthase expression in RAW 264.7 macrophages via the p38/ERK and NF- $\kappa$ B pathways," International Journal of Biochemistry and Cell Biology, vol. 40, no. 11, pp. 2572-2582, 2008.

[37] N. Márquez, R. Sancho, A. Macho, M. A. Calzado, B. L. Fiebich, and E. Muñoz, "Caffeic acid phenethyl ester inhibits t-cell activation by targeting both nuclear factor of activated t-cells and nf- $\kappa \mathrm{b}$ transcription factors," Journal of Pharmacology and Experimental Therapeutics, vol. 308, no. 3, pp. 993-1001, 2004.

[38] N. Paulino, S. R. L. Abreu, Y. Uto et al., "Anti-inflammatory effects of a bioavailable compound, Artepillin C, in Brazilian propolis," European Journal of Pharmacology, vol. 587, no. 1-3, pp. 296-301, 2008.

[39] A. C. Pagliarone, C. L. Orsatti, M. C. Búfalo et al., "Propolis effects on pro-inflammatory cytokine production and Toll-like receptor 2 and 4 expression in stressed mice," International Immunopharmacology, vol. 9, no. 11, pp. 1352-1356, 2009. 


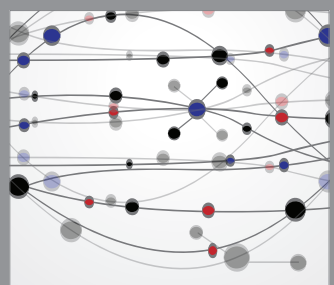

The Scientific World Journal
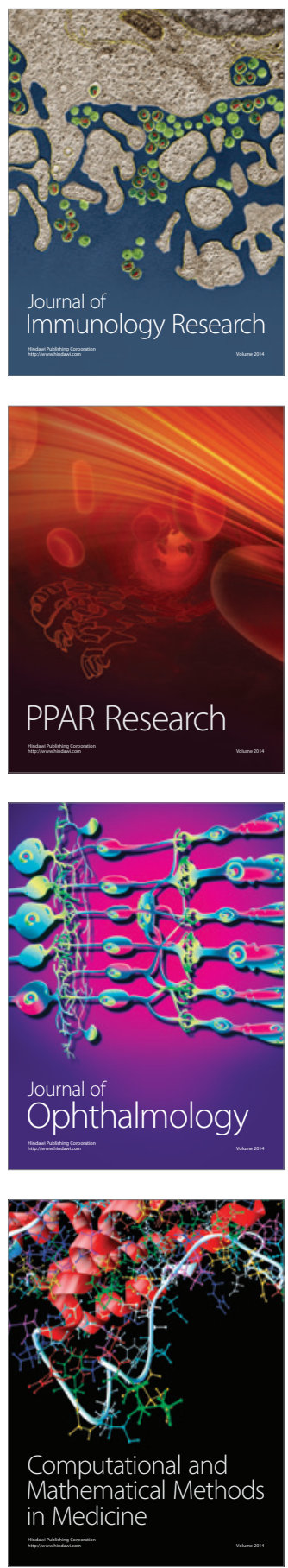

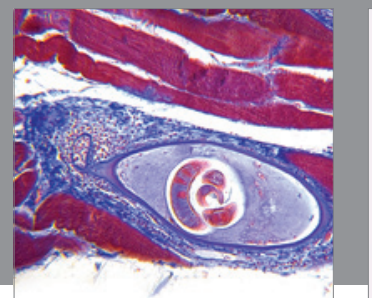

Gastroenterology

Research and Practice
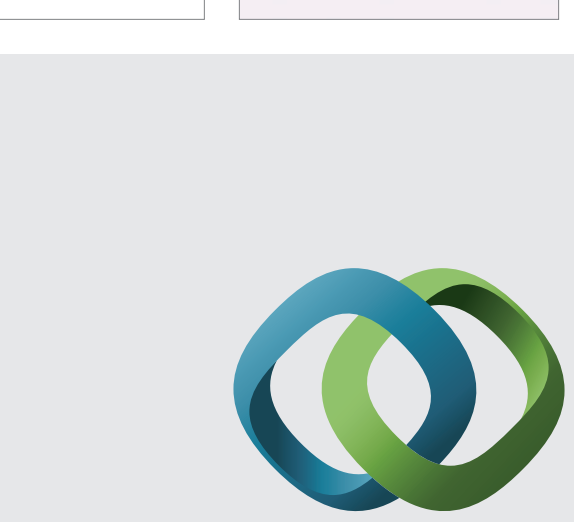

\section{Hindawi}

Submit your manuscripts at

http://www.hindawi.com
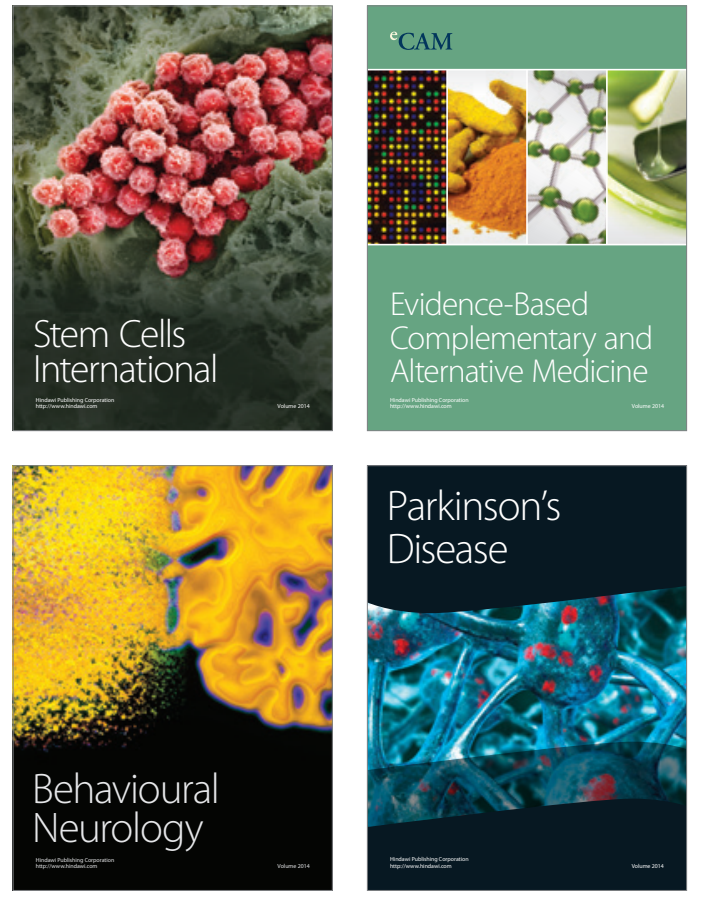
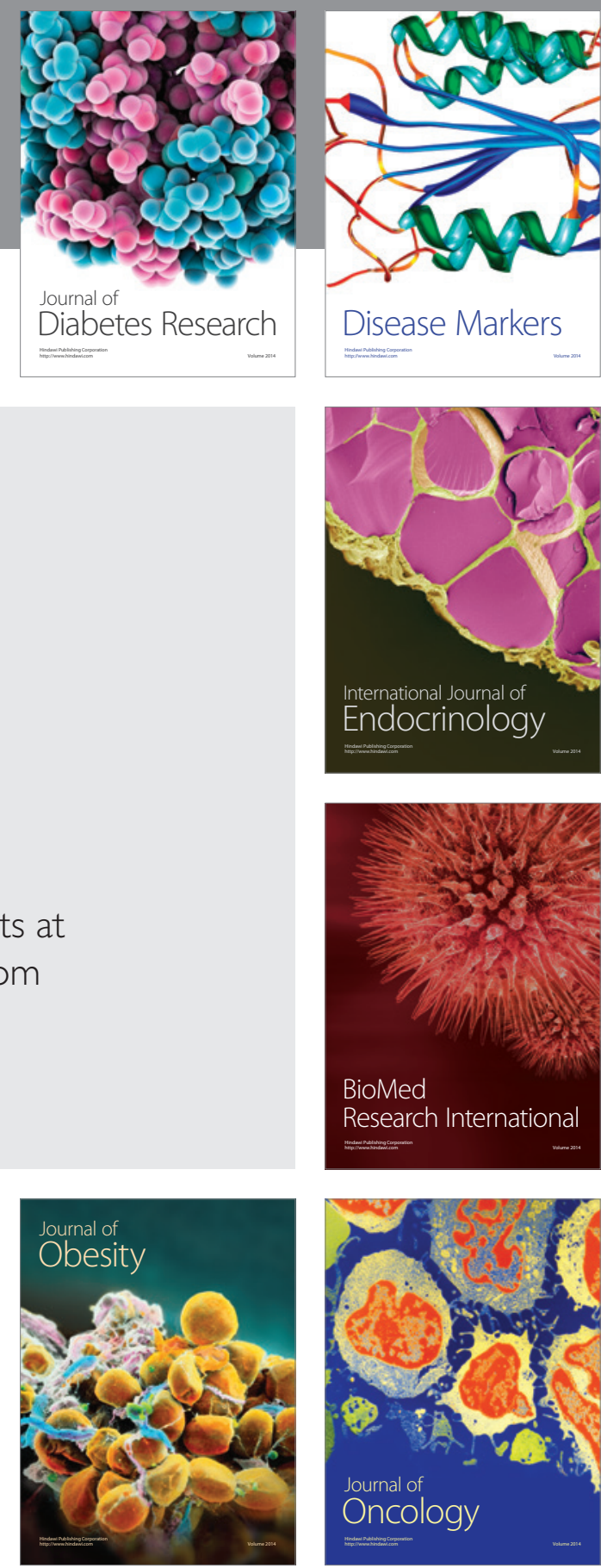

Disease Markers
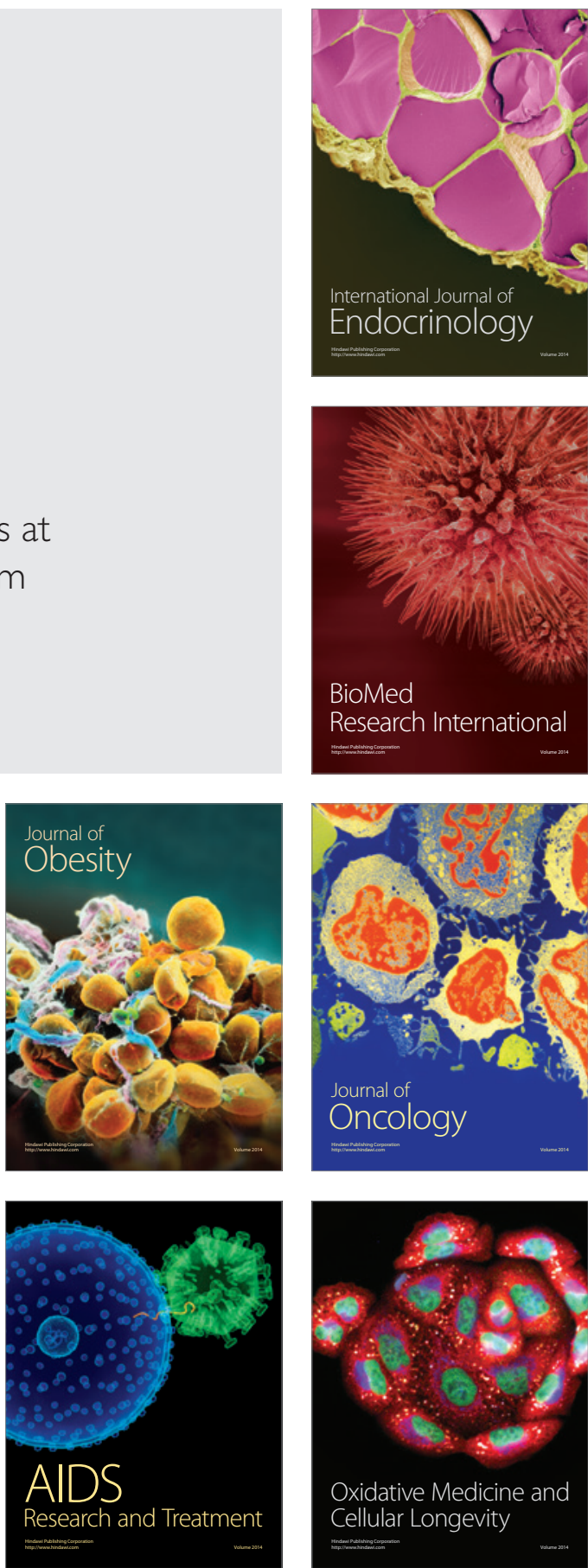